\title{
Can ecotourism change community attitudes towards conservation?
}

\author{
Jackie Ziegler, Gonzalo Araujo, Jessica Labaja, Sally Snow, Joseph N. King \\ Alessandro Ponzo, Rick Rollins and Philip Dearden
}

\begin{abstract}
A basic tenet of ecotourism is to enhance conservation. However, few studies have assessed its effectiveness in meeting conservation goals and whether the type of tourism activity affects outcomes. This study examines whether working in ecotourism changes the perceptions of and attitudes and behaviours of local people towards the focal species and its habitat and, if so, if tourism type affects those outcomes. We interviewed 114 respondents at four whale shark Rhincodon typus tourism sites in the Philippines to compare changes in perceptions of and attitudes and behaviours towards whale sharks and the wider marine environment. We found that the smaller scale tourism sites had greater social conservation outcomes than the mass or failed tourism sites, including changes in conservation ethics and perceptions of and attitudes and behaviours towards whale sharks and the ocean. Furthermore, of the three active tourism sites, the smallest site, with the lowest economic returns and the highest negative impacts on whale sharks prior to tourism activities, had the largest proportion of respondents who reported a positive change in perceptions of and attitudes and behaviours towards whale sharks and the ocean. Our results suggest that tourism type, and the associated incentives, can have a significant effect on conservation outcomes and ultimately on the ecological status of an Endangered species and its habitat.
\end{abstract}

Keywords Community-based tourism, conservation attitudes, conservation outcomes, ecotourism, incentive-based conservation, marine wildlife tourism, Rhincodon typus, whale shark

Supplementary material for this article is available at doi.org/10.1017/So030605319000607

JACKIE ZIEGLER (Corresponding author, (1) orcid.org/0000-0003-3748-956X) Marine Protected Areas Research Group, Department of Geography, University of Victoria, P.O. Box 3060 STN CSC, Victoria, British Columbia, V8W 3R4, Canada. E-mail jziegler@uvic.ca

Gonzalo Araujo, Jessica labaja, Sally Snow and Alessandro Ponzo Large Marine Vertebrates Research Institute, Jagna, Philippines

Joseph N. KING Conflict and Development Foundation, College Station, USA

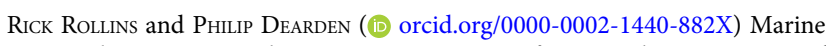
Protected Areas Research Group, Department of Geography, University of Victoria, Victoria, Canada

Received 10 February 2019. Revision requested 16 April 2019.

Accepted 29 May 2019. First published online 5 May 2020.

\section{Introduction}

Tncentive-based conservation provides incentives (e.g. employment, ecological services, compensation payments, health care, education, agroforestry, tourism development/promotion) to gain support for conservation (Spiteri \& Nepal, 2006). Such approaches are based on the belief that benefits derived directly from natural resources will encourage conservation and sustainable use of those resources (Stronza, 2007). Social conservation outcomes of these projects include improved conservation awareness and attitudes and an increase in pro-conservation behaviours. Community participation in conservation projects and the receipt of economic and social benefits from these projects may lead to improved conservation perceptions and attitudes, which may, in turn, lead to pro-conservation behaviours (Stem et al., 2003; Pegas et al., 2013). Reduction in negative behaviours (e.g. poaching) and increase in positive behaviours (e.g. participation in conservation projects) can lead to positive conservation outcomes (e.g. increased species abundance and/or range; Holmes, 2003).

The relationship between incentive-based conservation projects and improved attitudes, awareness and behaviours is complex. Economic benefits from such projects do not necessarily result in increased support for conservation (Walpole \& Goodwin, 2001), nor do positive perceptions of conservation always lead to pro-conservation behaviours (Mintzer et al., 2015; Nilsson et al., 2016). Nevertheless, improving attitudes towards conservation is important in its own right and in some circumstances may be the most effective intervention for achieving conservation goals.

Although ecotourism has been widely adopted as a conservation tool, few studies have evaluated its effectiveness in meeting conservation goals, largely in the terrestrial environment (see Wardle et al., 2018 for a review). Ecotourism is sustainable, nature-based tourism that enhances conservation (Buckley, 1994). This often occurs through the economic benefits provided by tourism that supplant other economic and, often, extractive uses of the focal species. The focal species may be worth more alive than dead and therefore it is in the community's interest to protect the species. Many studies have documented this economic impact analysis (Cisneros-Montemayor et al., 2013; Venables et al., 2016). However, other impacts also occur in communities that host ecotourism. Changing perceptions of the target species by those involved in ecotourism may also benefit conservation outcomes (Bennett, 2016). These 
changing perceptions may lead to behaviours that are more supportive of conservation (Stem et al., 2003). Such changes may ultimately be more transformative and stable than economic impacts that are vulnerable to changing demands and the success of the enterprise. However, little research has addressed these social conservation outcomes and the factors that may influence them (Wardle et al., 2018). This study addresses this gap through a comparative study of four types of whale shark Rhincodon typus tourism in the Philippines (the whale shark is categorized as Endangered on the IUCN Red list; Pierce \& Norman, 2016). It seeks to understand whether changes have taken place in terms of local perceptions of and attitudes and behaviours towards whale sharks and the wider ocean environment and whether these differ according to the type of tourism undertaken.

\section{Study sites}

The four study sites are in the Philippines. Oslob, Cebu, has a population of 27,893 (Philippine Statistics Authority, 2019; Fig. 1). Open since 2011, Oslob whale shark tourism is a community-based mass tourism site. It is the largest noncaptive whale shark tourism site globally, with c. 508,000 tourists annually and generating c. USD 10 million in revenue in 2018 (Ziegler et al., 2019a). Unlike most other whale shark tourism sites that are dependent on seasonal aggregations of sharks, tour operators at Oslob feed the whale sharks c. $350 \mathrm{~kg}$ of uyap (small shrimp) daily during 6.0012.00 (Ziegler et al., 2019b). Tourists are paddled $50 \mathrm{~m}$ from shore for 30 minutes in the viewing area, where feeder boats lead the sharks between lines of tourist boats. Viewing is guaranteed. This compares with tourist boats at non-provisioned locations that may spend 3-4 hours searching for sharks they may, or may not, see. Provisioning is therefore critical to ensure activities can occur year-round and support a mass tourism business model at Oslob. A total of 208 individual whale sharks have been identified at this site, with a mean weekly abundance of 18.6 (Thomson et al., 2017).

Donsol, Sorsogon, has a population of 49,711 (Philippine Statistics Authority, 2019). Established in 1998, Donsol was the first whale shark tourism site in the Philippines. The local community, with the help of WWF-Philippines, pushed for the creation of tourism activities after the killing of seven whale sharks in their waters led to a ban on the hunting of whale sharks in the country (Pine, 2007). This site represents a mid-tier tourism site. During the 2017 season the site had 14,191 visitors and revenue of USD 800,000 (Ziegler \& Dearden, in press). Prior to 2012, Donsol was one of the largest non-captive shark viewing sites globally in terms of tourist numbers. However, recent issues with variability in whale shark sightings (few whale sharks were sighted during the 2013, 2014 and 2018 seasons) has resulted in a decline in visitation. A total of 479 individual whale sharks have been identified at this site, with annual variation in sightings ranging from 185 individual sharks in 2009 to 15 in 2013 (McCoy et al., 2018).

Pintuyan, Southern Leyte, has a population of 9,826 (Philippine Statistics Authority, 2019). This site represents a small-scale tourism site. Started in 2006, visitation is only a few hundred to a thousand people annually, depending on the length of the season, as whale shark sightings are highly variable. For example, the 2016 and 2017 seasons lasted $<2$ months, whereas the 2018 season lasted 7 months. A total of 93 individual whale sharks have been identified at this site, with 92 sharks encountered in 2013 and only 7 sharks in 2014 (Araujo et al., 2017). Revenue was USD 56,000 in 2018 (Ziegler \& Dearden, in press). There is no tourism infrastructure in the village. Although whale shark guides and spotters are members of a community-based people's organization (KASAKA), they are reliant on foreignowned dive shops for their clientele. A local ordinance requires dive shops offering whale shark tours to employ local spotters and guides.

Talisayan, Misamis Oriental, was formerly one of the main whale shark hunting villages in the Philippines (Alava et al., 2002) and has a population of 24,505 (Philippine Statistics Authority, 2019). This site is a failed tourism site. Prior to the 1998 hunting ban, hunters were promised a PHP 300 (USD 7) daily income from work in whale shark tourism if they agreed to halt shark hunting. Although some hunters formed the Whale Shark Spotters Association in 1997, whale shark tourism failed to develop. Despite the efforts of multiple local, national and international organizations (WWF-Philippines, Department of Tourism, Bureau of Fisheries and Aquatic Resources, Silliman University, and a local dive resort), ecotourism failed largely because a feasibility assessment was never completed. It is difficult to find whale sharks for tourism purposes at this site (e.g. 3.5 hours per whale shark sighted in a boat survey in 2017; Araujo \& Labaja, 2017). The whale shark aggregation at Donsol became prominent during this time and the attention shifted to protecting that aggregation (A. Yaptinchay, pers. comm., 2019). This is a failed tourism site as a result of the unsuccessful attempt to involve whale shark hunters in tourism activities.

\section{Methods}

We conducted interviews with whale shark tourism operators at the three active tourism sites (Oslob, Donsol and Pintuyan) during April-June 2016 (Supplementary Material 1) and with ex-whale shark hunters and fishers at the failed tourism site (Talisayan) during May-June 2017 (Supplementary Material 2). At the three active tourism 


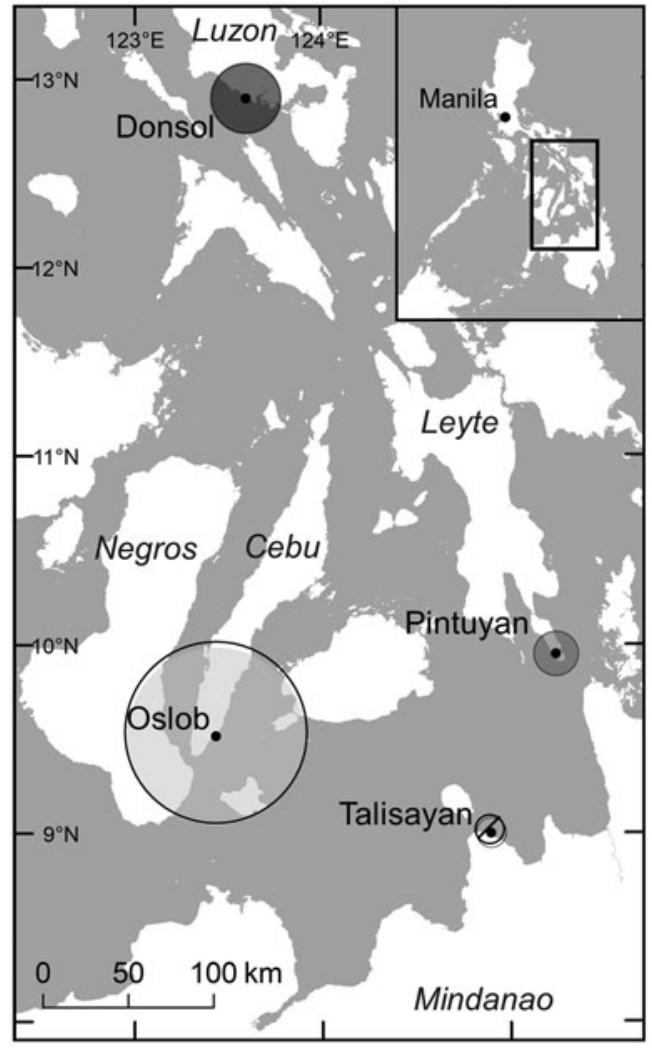

- Study site

$\oslash$ Failed site

Number of visitors per year

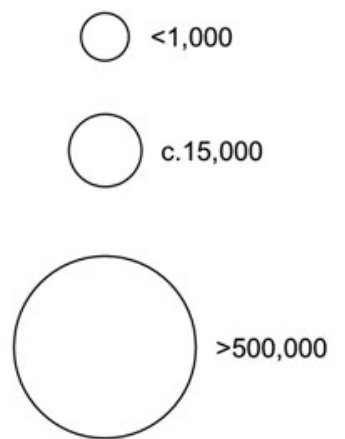

Years in operation

5

10

$>15$
FIG. 1 The four tourism study sites in the Philippines, with the number of visitors per year and number of years in operation. sites, JZ and a local translator conducted interviews in the local dialect, translating answers into English during the interviews. Because of travel restrictions to the island of Mindanao, JL conducted the interviews in Talisayan and translated the transcripts into English.

Sampling varied at each site. In Pintuyan, we interviewed all 40 KASAKA members as the organization is small. In Oslob, the president of the Tan-awan Oslob Sea Wardens and Fishermen Association randomly picked workers to be interviewed from those on-site that day who were not on the water or working frontline positions. In Donsol, respondents were randomly selected from those at the site who were not out on the water. We tried to approach every available operator during a given 5 -hour period, to include as many people as possible. In Oslob the final sample size was limited to 25 interviews by the president of the Tan-awan Oslob Sea Wardens and Fishermen Association, who had to give permission for workers to participate. In Donsol the final sample size was limited to 24 interviews by the early departure of the whale sharks that season (some of those who work in tourism leave Donsol in the off-season, and as the community of Donsol is large it is difficult to interview those who work in tourism, especially boat crews, if they are not at the tourism launch site). In Talisayan we interviewed all 17 exwhale shark hunters in the village and eight opportunistically selected fishers. We reached data saturation at each of the sites (i.e. no new themes, no new codes in the analysis, no new data; Guest et al., 2006) suggesting that the sample sizes were adequate to reflect perspectives at each of the sites, as well as of a sufficient number to perform statistical analyses.

We used structured interviews, using a combination of open- and closed-ended questions, to collect information at the four sites. Respondents were asked about their livelihoods, their perceptions of whale shark tourism activities, including its impact on the economy, the environment, the community and their families, and the perceived importance of whale sharks and the ocean. Respondents were also asked if their perceptions of and attitudes and behaviours towards whale sharks and the ocean had changed since whale shark tourism activities started in their community (Oslob, Donsol, Pintuyan) or since the ban on whale shark hunting was implemented (Talisayan). Respondents were asked to rate their desire to protect whale sharks and the ocean on a four-point Likert scale from 1 (none) to 4 (a lot). Tour operators were asked if working in tourism changed the amount of fishing they did and, if so, by how much, and regarding their main income source before and after tourism activities started. Interview data were entered into SPSS 25.0 (IBM, Armonk, USA) for quantitative analysis and open-ended questions were entered and coded in NViVO 12.o (QSR International, Melbourne, Australia) for qualitative analysis. 


\section{Results}

\section{Livelihood characteristics}

The majority of respondents at each site were fishers. Respondents at the failed site were significantly more likely to fish full-time than those at the other sites (Table 1). The main income sources by site were tourism at the mass tourism site, fishing at the failed and mid-tier sites, and 'other' (e.g. labour, professional, agriculture) at the small-scale site.

Respondents from the mid-tier site had been working in tourism 2-3 times longer than respondents from other sites. However, respondents from the provisioned mass tourism site made $2-3$ times the daily income of respondents at the non-provisioned sites and 8-9 times their annual income (Table 1). This number increased to $16-34$ times the annual income of the non-provisioned sites during seasons with poor whale shark sightings. This difference in income is a result of the provisioned nature of tourism activities at the mass site, where operators are able to work every day because the sharks are always present. At the non-provisioned sites, where whale shark presence is seasonal, operators are only able to work 6-7 months per year, and only 3 days per week on average because guides work on a rotational basis; if there are few tourists or sharks, an operator will only work every other day or every other 2 days (rather than every day, as at the provisioned site).

\section{Perceived benefits of whale shark tourism}

At all four sites, benefits of whale shark tourism were largely perceived to be economic (Table 2); respondents from the more established, profitable sites (mass, mid-tier) were significantly more likely to report community improvement, improved job opportunities and improved quality of life (e.g. 'My children are now in school because of whale sharks; my house is possible because of whale sharks') compared to the small-scale and failed sites where respondents mainly perceived the economic benefits as livelihood benefits (e.g. 'The allowance from [my] job as a spotter [...] helps us buy the basic necessities for the family, e.g. $1 \mathrm{~kg}$ of rice'). Respondents from the smaller scale sites (small-scale, mid-tier) were significantly more likely to mention conservation outcomes of whale shark tourism, (e.g. 'tourism has affected the ocean and whale sharks in a positive way because now they are protected'), compared to the mass tourism or failed tourism sites.

\section{Conservation outcomes}

Changes in fishing Our results suggest that commercial success is important for overall reduction in extractive activities. Although the number of fishers who stopped fishing was not significantly different among the tourism sites,

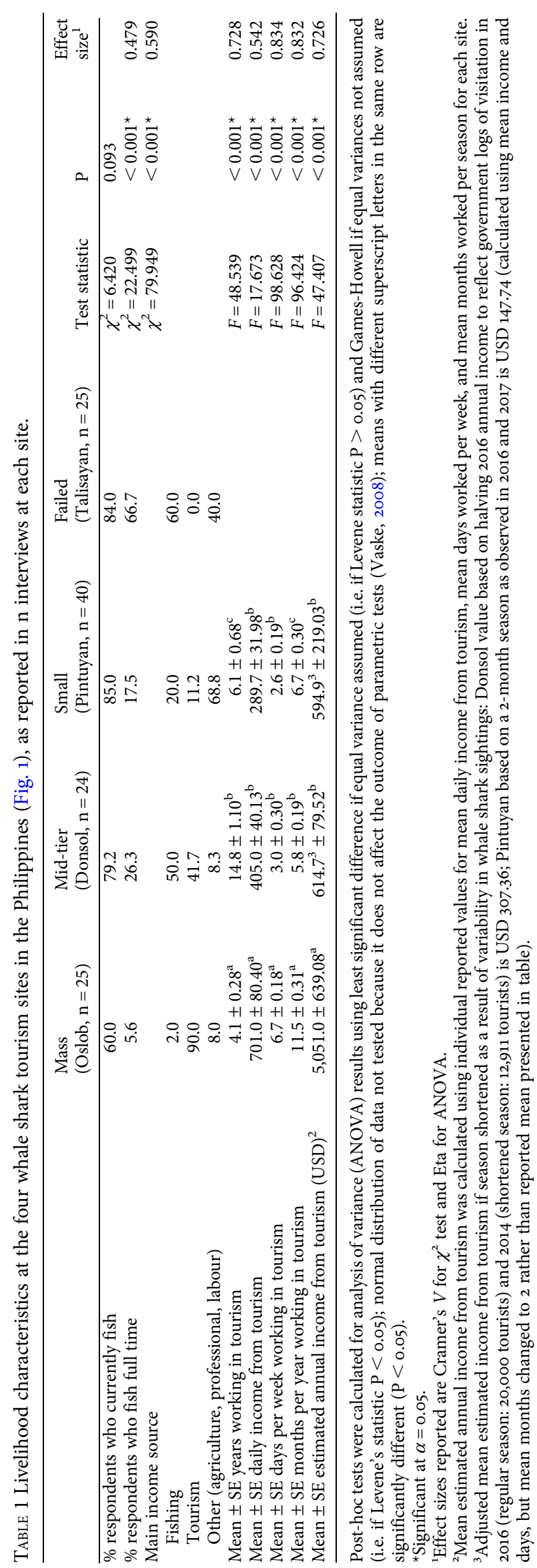


TABLE 2 Perceived benefits of whale shark tourism at the four tourism sites, as reported in $\mathrm{n}$ interviews at each site.

\begin{tabular}{|c|c|c|c|c|c|}
\hline Perceived benefits & $\begin{array}{l}\text { Mass } \\
(\text { Oslob, } n=25)\end{array}$ & $\begin{array}{l}\text { Mid-tier } \\
(\text { Donsol, } \mathrm{n}=24)\end{array}$ & $\begin{array}{l}\text { Small } \\
\text { (Pintuyan, } \mathrm{n}=40 \text { ) }\end{array}$ & $\begin{array}{l}\text { Failed } \\
\text { (Talisayan, } \mathrm{n}=25 \text { ) }\end{array}$ & Total \\
\hline Economics (\% response) & 74.2 & 69.8 & 72.9 & 83.4 & 228 \\
\hline Livelihood (n) & 21 & 21 & 40 & 21 & 103 \\
\hline Community improvement (n) & 19 & 19 & 9 & 6 & 53 \\
\hline Job opportunity (n) & 12 & 14 & 6 & 2 & 34 \\
\hline Improved quality of life (n) & 17 & 11 & 0 & 1 & 29 \\
\hline Tourist attraction $(\mathrm{n})$ & 0 & 2 & 7 & 0 & 9 \\
\hline Conservation outcomes (\% response) & 8.6 & 22.9 & 20.0 & 8.3 & 50 \\
\hline Environmental (n) & 4 & 14 & 5 & 3 & 26 \\
\hline Improved knowledge (n) & 1 & 8 & 11 & 0 & 20 \\
\hline Educate others $(\mathrm{n})$ & 2 & 0 & 1 & 0 & 3 \\
\hline Emotional connection to marine wildlife (n) & 1 & 0 & 0 & 0 & 1 \\
\hline Social (\% response) & 17.2 & 7.3 & 7.1 & 8.3 & 32 \\
\hline Learn languages $(\mathrm{n})$ & 10 & 5 & 4 & 0 & 19 \\
\hline Cultural (n) & 5 & 2 & 2 & 2 & 11 \\
\hline Self-worth (n) & 1 & 0 & 0 & 1 & 2 \\
\hline Total & 93 & 96 & 85 & 36 & 310 \\
\hline
\end{tabular}

Statistical difference amongst sites in terms of frequency of mentioning the three main perceived benefits (economics, conservation outcomes, social): $\chi^{2}(6, \mathrm{n}=310)=14.954, \mathrm{P}=0.021$, Cramer's $V=0.155$.

the majority of fishers from the mass tourism site reported a reduction in the amount of time they spent fishing compared to the smaller scale tourism sites (Table 3). Oslob is also the only site where the majority of respondents $(n=24)$ obtain their main income from whale shark tourism activities. Nearly half the respondents had transitioned from fishing to tourism as their main income source, seven did not rely on fishing as their main income source prior to tourism activities, and five never fished. As tourism activities are seasonal at the mid-tier site, only seven respondents reported a change from fishing to tourism as their main income source, with a further three not relying on fishing as their main income source prior to tourism activities, and two having never fished. Fishers at the small-scale site did not make enough money nor work sufficient days in tourism to warrant a significant change in the amount of time spent fishing. Only five fishers reported a decrease in fishing as a result of tourism activities at this site. None of the respondents at this site had transitioned from fishing to tourism as their main income source.

Changes in perceptions of whale sharks Respondents from the smaller scale sites (mid-tier, small-scale) had significantly greater reported changes in perceptions of whale sharks compared to the mass and failed tourism sites (Table 3). For example, most respondents $(n=36)$ at the small-scale site noted they now cared about, and valued, whale sharks, and the majority of respondents $(n=15)$ from the mid-tier site noted they were no longer afraid of the sharks because of tourism activities. Other changes in perceptions at these sites included the benefit the presence of whale sharks brings to local fisheries ('my fishing has increased by $80 \%$ because whale sharks [...] bring many small fishes to the community'), no longer perceiving whale sharks to be pests with regards to fishing ('before tourism, I would get really angry with the whale sharks because they eat plankton and fish like tuna or any small fishes, and it was competing with me for food'), and an emotional connection to the sharks as a result of tourism activities:

I really want to protect whale sharks because of one interaction I had with a whale shark as a spotter where I was very happy seeing the whale shark, I felt like we played or danced under water. I really felt very happy looking at the whale shark, that's why it should be protected.

At the failed tourism site, the vast majority of respondents held negative views of the sharks $(n=20)$. Of the 13 respondents who did note a change in perception of whale sharks since the ban, this change was largely negative $(n=12)$, mainly a result of the perception that the sharks are now dangerous (e.g. '[whale sharks] are more ferocious [now], they destroy our boats') or a pest having a negative impact on their fishery (e.g. 'the way I see it, [the whale shark] eats small fishes [...] it is the reason for the crisis of fish offshore'). Only one respondent from the site reported a positive change related to improved fishing.

Nearly three quarters of respondents at the mass tourism site reported a positive change in perception of whale sharks. As at the mid-tier site, many were no longer afraid of the sharks and/or held positive views of whale sharks because of the income they generate. Of those who noted their perceptions had not changed since tourism activities started $(n=7)$, two already had a positive perception of the sharks and five encountered their first whale shark on their first day working in tourism. 


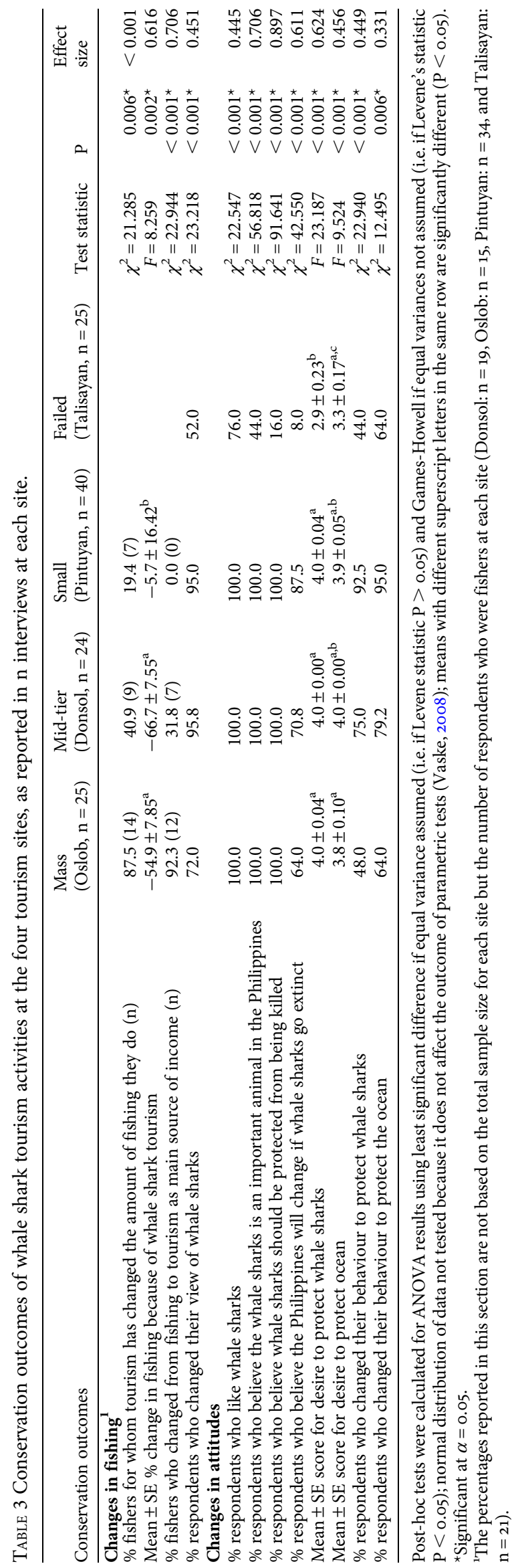

Changes in attitudes towards whale sharks All respondents at the active tourism sites reported liking whale sharks, whereas only $76 \%$ of respondents from the failed tourism site did so (Table 3). Two respondents at the failed site noted, however, that they only liked whale sharks for the purposes of hunting them and the majority of respondents at this site noted a desire to continue hunting the sharks if it were still legal $(n=22)$. Less than half of the respondents from the failed site believed whale sharks to be an important animal in the Philippines compared to all respondents from the three active tourism sites, with one respondent noting that whale sharks were important in terms of food and/or livelihood from hunting. Only four respondents from the failed site felt that whale sharks should be protected from being killed, whereas all respondents from the tourism sites felt they should be protected. The majority of respondents from the active tourism sites felt that the Philippines would change if whale sharks were to go extinct, with several noting they would lose their source of income, but only two respondents from the failed site agreed with this statement.

Conservation ethics Respondents from the failed tourism site were significantly less likely to want to protect whale sharks compared to respondents at the active tourism sites (Table 3). They were also significantly less likely to want to protect the ocean compared to respondents at the smaller scale sites, but not the mass tourism site; the mass site was not significantly different from any of the other sites in terms of desire to protect the ocean (Table 3 ).

Changes in behaviour Respondents from the smaller scale sites were more likely to have changed their behaviour to protect the whale sharks compared to respondents from the mass tourism and failed tourism sites (Table 3), mainly in terms of no longer hurting the sharks, telling others to protect the sharks, and ensuring everyone follows the encounter guidelines (Table 4). Most respondents at the small-scale site reported interacting with the sharks prior to tourism activities by hitting them with stones or paddles, striking them with harpoons or dynamite, or riding them $(n=26)$ :

We had bamboo sticks and we would sharpen the tip so [it was] like a harpoon and we would throw it at the whale sharks; [we] would also [attach] a fishing line when we would throw the stick so we could hold on and ride the shark, not to kill the shark, just to play.

Three respondents mentioned killing the sharks either incidentally as bycatch or intentionally:

Before tourism, I was bad, I did bad things to whale sharks. I killed them, I caught them on purpose to eat the whale shark. Some [sharks were] caught as bycatch in nets, others I killed by throwing dynamite sticks at them or using a harpoon. We would dry the meat and eat it. $[\ldots]$ Now, we leave the whale sharks alone.

Nearly half of respondents at the small-scale site also noted they now tell others to protect the sharks or report those 
TABLE 4 Self-reported behavioural changes towards whale sharks and the ocean at the four tourism sites, as reported in $\mathrm{n}$ interviews at each site.

\begin{tabular}{|c|c|c|c|c|}
\hline & $\begin{array}{l}\text { Mass (Oslob, } \\
\mathrm{n}=25)\end{array}$ & $\begin{array}{l}\text { Mid-tier (Donsol, } \\
\mathrm{n}=24 \text { ) }\end{array}$ & $\begin{array}{l}\text { Small (Pintuyan, } \\
\mathrm{n}=40 \text { ) }\end{array}$ & $\begin{array}{l}\text { Failed (Talisayan, } \\
\mathrm{n}=25)\end{array}$ \\
\hline \multicolumn{5}{|l|}{ Changed behaviour towards whale sharks? $^{1}$} \\
\hline Yes (\% response) & 48.0 & 75.0 & 92.5 & 44.0 \\
\hline No longer harm or kill the sharks (n) & 8 & 12 & 26 & 4 \\
\hline $\begin{array}{l}\text { Tell others to protect the shark or report those } \\
\text { who harm sharks to authorities (n) }\end{array}$ & 3 & 7 & 17 & \\
\hline Follow the encounter guidelines (n) & & 4 & 8 & \\
\hline Release whale sharks from net or fish corral (n) & 1 & & 3 & 8 \\
\hline Change fishing gear or approach $(\mathrm{n})$ & & 2 & & \\
\hline No longer throw rubbish in the ocean (n) & & 1 & 2 & \\
\hline Work in tourism $(\mathrm{n})$ & & & & 1 \\
\hline No (\% response) & 52.0 & 25.0 & 7.5 & 56.0 \\
\hline Never hurt whale sharks (n) & 10 & 6 & 2 & - \\
\hline \multicolumn{5}{|l|}{ Changed behaviour towards the ocean ${ }^{2}$} \\
\hline Yes (\% response) & 64.0 & 79.2 & 95.0 & 64.0 \\
\hline Pick up rubbish or dispose of it appropriately (n) & 13 & 13 & 23 & 3 \\
\hline Use more sustainable fishing gear/approaches (n) & 4 & 3 & 10 & 5 \\
\hline Tell others to protect the ocean $(\mathrm{n})$ & 2 & 4 & 7 & 4 \\
\hline Report illegal activities (n) & & & 3 & 4 \\
\hline Other environmental behaviours (n) & & 1 & 1 & 1 \\
\hline No (\% response) & 36.0 & 20.8 & 5.0 & 36.0 \\
\hline Always protected (n) & 3 & 4 & 2 & 1 \\
\hline
\end{tabular}

${ }^{1} \chi^{2}(3, \mathrm{n}=114)=22.940, \mathrm{P}<0.001$, Cramer's $V=0.449$.

${ }^{2} \chi^{2}(3, \mathrm{n}=114)=12.495, \mathrm{P}=0.003$, Cramer's $V=0.331$.

who harm them to the appropriate authorities, as a result of the presence of tourism activities at the site $(n=17)$ :

A neighbouring barangay had an incident last year where I saw people hurting a whale shark and I fought for the whale shark not to be harmed and it was eventually released unharmed. [...] They had caught it in a net and the people there wanted to tie it and kill it.

Less than half of respondents from the mass tourism site reported a behavioural change $(n=12)$, mostly in terms of following the encounter guidelines, specifically no longer touching or riding the sharks $(n=7)$. Ten respondents at this site did not report a behavioural change because they had not seen a whale shark until their first day on the job $(n=3)$ or they had never hurt the sharks $(n=7)$.

At the failed site, the majority of respondents reported no change in their behaviours to protect the sharks since the ban was implemented $(n=14)$, with one respondent noting when asked if he would release a shark if it got caught in his net 'no, kill it, kill the whale shark, drown it'. Of the eleven respondents who did report a change in behaviour at the site, the majority reported releasing sharks from nets $(n=8)$ and or no longer killing them $(n=4)$.

Respondents at the small-scale site were also significantly more likely to have reported behavioural changes with respect to the ocean compared to the other tourism sites (Tables $3 \& 4$ ). The majority of respondents from the tourism sites who reported a behavioural change did so with respect to how they dealt with rubbish, both in terms of disposal and cleaning up rubbish they found. Another behavioural change at all four sites was telling others to care for the ocean (e.g. 'I tell people who use illegal fishing methods like cyanide [...] that it's not so good because it kills our future; they are eating now but children are our future and they won't have any fish'). At the small-scale and failed tourism sites, respondents also noted they report those who are breaking the law. A few respondents at each site also noted they now use more sustainable fishing practices or approaches. For example, they no longer use destructive fishing methods such as muro-ami (i.e. in which compressor divers use heavy weights to pound the corals and scare the fish into a fixed net), cyanide, night fishing with spearguns, bato bato (i.e. in which the fisher hits and breaks coral to obtain fish), and fine gill nets. They were also more selective in the fish they catch and respect fishing regulations in place: 'I don't catch any undersize fish and I don't fish in the sanctuary. I give importance to the sanctuary as a place for the production of fishes'. One respondent from the mid-tier site noted that he has stopped fishing 'because I'm trying to protect the ocean'. Three others noted their participation in environmental activities, such as planting mangroves, the removal of crown-of-thorn starfish from their local reef, and removing a fishing line from a manta. Of the nine respondents each at the mass and failed tourism sites who did not report a behavioural change towards the ocean, only three and one, respectively, said that it was because they always protected it. 


\section{Discussion}

Our results suggest that participation in tourism results in significant positive changes in perceptions and behaviours of local operators, both towards the target species and the wider marine environment. However, the type of tourism activity appears to affect conservation outcomes. Respondents from the smaller scale tourism sites reported greater social conservation outcomes compared to the mass or failed tourism sites, including changes in perceptions of and attitudes and behaviours towards whale sharks and the ocean. They were also more likely to perceive whale shark tourism activities as providing more conservation benefits to the sharks and community than the failed or mass tourism sites. Although a number of respondents from the mass tourism site reported fewer changes in their behaviour towards whale sharks because they had never seen a whale shark prior to working in tourism, this would not preclude them from behavioural changes mentioned at the other sites, such as telling others to protect the sharks or no longer throwing rubbish in the ocean. These results suggest that respondents at the mass tourism site were either less likely to change their behaviour to protect sharks and/or were less likely to recognize the importance of their behavioural changes on the whale sharks. For example, half the respondents at the mass tourism site reported properly disposing rubbish to protect the ocean, and yet none did so in the context of protecting whale sharks.

Although tourism businesses must be commercially successful to deliver benefits to conservation and local communities (Seales \& Stein, 2012), our research suggests that the type of tourism is also important. Although respondents from the small-scale site reported the smallest economic returns of the three active tourism sites assessed, they had the largest proportion of respondents who reported positive change in perceptions of and behaviours towards whale sharks and the ocean. Respondents from this site were also significantly more likely to have reported harming whale sharks prior to tourism activities than the other active tourism sites. These findings suggest that even a small-scale tourism activity can have significant conservation outcomes for an Endangered species and supports placing emphasis on establishing small-scale ecotourism initiatives within priority fishing communities (i.e. those with larger ecological impacts) for maximum conservation benefits.

Previous studies support the importance of non-economic incentives in generating conservation outcomes. Stem et al. (2003) found that non-cash benefits were more strongly associated with conservation perspectives than direct cash benefits. Similarly, Nilsson et al. (2016) found that behavioural changes towards orangutans Pongo abelii were most likely to occur in villages with small-scale tourism or a community-based reforestation programme, and least likely to occur in a village with mass tourism activities. These authors further found that only non-economic incentives had any effect on changes in behaviours or attitudes towards protecting critical orangutan habitat, regardless of the nature of conservation projects present. Nilsson et al. (2016) concluded that economic benefits are key to catalyse local support for conservation projects in the short-term, especially in developing countries with limited economic opportunities, but that non-economic incentives are critical for the long-term viability of conservation projects and should be considered in the design and implementation of incentivebased conservation projects.

We also found a lack of connection between economic incentives and attitudinal and behavioural changes beyond the focal species. Respondents from the three active tourism sites were more likely to want to protect whale sharks than respondents at the failed tourism site. However, this did not equate to a desire to protect the ocean. Although respondents from the smaller scale tourism sites were more likely to want to protect the ocean compared to respondents at the failed tourism site, respondents from the mass tourism site were not. This suggests that the significant economic benefits the mass tourism site derives from whale shark tourism do not, as yet, translate into conservation benefits for the greater marine environment. Whether this will change remains to be seen.

The lack of control villages in the study, and the fact that the sites varied in terms of geography, duration of tourism operations and NGO presence, make it difficult to draw conclusions regarding the direct causality between type of tourism present and difference in social conservation outcomes amongst the sites. For example, WWF-Philippines provided capacity training to Donsol to facilitate the development of whale shark tourism in 1998 and was involved in tourism management and outreach at this site during 2007-2015. The Large Marine Vertebrates Research Institute Philippines has been involved at all three active tourism sites (Oslob since 2012, Pintuyan since 2012, Donsol since 2015), primarily carrying out scientific studies but also providing some outreach for the communities involved. However, the smallest site (Pintuyan, open 10 years) with less NGO presence than Donsol (mid-tier, open 18 years) and similar outreach to Oslob (mass tourism, open 5 years), still had more social conservation outcomes. This suggests that observed differences in perceptions, attitudes and behaviours are probably a result of the type of tourism present and not of outside factors. Regardless, future work is needed to include control sites, to explore the role of NGOs, geography and duration of tourism operations on conservation outcomes.

Results from the failed site suggest that tourism may not be the main driver of changes in behaviour. Although respondents at this site held largely negative perceptions of and attitudes towards whale sharks and reported a lower desire to protect both the sharks and ocean compared to the 
smaller scale tourism sites, many fishers reported releasing the sharks from corrals or fishing nets and no longer killing them because of the risk of imprisonment if caught. Previous studies have found similar results (Stem et al., 2003). For example, Mintzer et al. (2015) found that fishers who did not like the Amazon River dolphin Inia geoffrensis still released them from their nets when near a protected area because of the fear of being caught killing a protected species rather than because of an inherent conservation ethic.

Our findings suggest that commercial success is important for overall reduction in extractive activities. Although the number of fishers who stopped fishing was not significantly different among the tourism sites, the majority of fishers from the mass tourism site reported a significant reduction in their fishing compared to the smaller scale tourism sites. Previous research has also found a similar link between employment in tourism and a reduction in extractive activities such as hunting or farming (Stem et al., 2003; Stronza, 2007). However, this reduction in local fishing pressure may not result in healthier fish stocks if fisheries are not well managed. For example, interviews with fishers in a neighbouring barangay within the municipality of Oslob identified issues with decreased catch, the use of illegal fishing methods, and commercial vessels fishing in municipal waters (J. Ziegler, unpubl. data), and in Donsol it was reported that commercial purse seiners in municipal waters removed 10 times the municipal annual fishery harvest each year (Pine, 2007; The Manila Times, 2013). In 2013, there were 350 commercial fishing boats bottom-trawl fishing in the Bicol region, which includes Donsol waters (The Manila Times, 2013); bottom-trawl fishing in municipal waters, bays and other fishery management areas is illegal in the Philippines, as is fishing with commercial vessels in municipal waters (Republic Act No. 10654 amending Philippine Fisheries Code 1998 (Republic Act No. 8550) 2014). Part of the problem is the decentralized nature of fisheries governance in the Philippines; municipalities with little funding or resources are expected to enforce fisheries laws in their waters, including apprehending commercial fishing vessels (Almendral, 2018; Ignacio, 2018). The impacts of such continued overfishing are stark. An assessment of coral reef health in the Philippines during 2015-2017 found that there were no remaining reefs in excellent condition, with $>90 \%$ of reefs classified as poor or fair (Almendral, 2018).

The type of tourism present may also have negative impacts on the marine environment. For example, Wong et al. (2019) assessed the effect of provisioning activities at Oslob on the health of local coral reefs and found signs of increased reef degradation at the provisioning site relative to a control site, including higher macroalgal cover, lower coral cover, and dominance of stress-tolerant coral genera (e.g. Pocillopora, Porites). Studies have also found that provisioning activities at this site are negatively affecting whale shark health and well-being (Araujo et al., 2014; Schleimer et al., 2015; Thomson et al., 2017), although there is disagreement within the scientific community regarding these impacts (Ziegler et al., 2018, 2019b,c; Meekan \& Lowe, 2019). Furthermore, the high volume of tourists at the mass tourism site increases the demand for food (c. 508,000 tourists in 2018 vs the Oslob municipal population of 27,893 ; Philippines Statistics Authority, 2019), which will increase pressure on local marine resources (e.g. King, 1997). Studies of the health of local coral reefs and fish stocks are required at these sites before conclusions can be drawn regarding any positive impact of whale shark tourism on ocean conservation.

Our study suggests that ecotourism can be an effective means of enhancing protection by positively changing local perceptions of and attitudes and behaviours towards target species and their respective ecosystems. However, the type of tourism present appears to play an important role in terms of the scale and scope of the conservation impacts. These findings suggest that although economic returns are important, they are not the main determinant of conservation outcomes and should not be the main metric used to assess conservation success of ecotourism sites. Conservation practitioners should be aware that even smallscale ecotourism ventures can result in significant benefits for conservation.

Acknowledgements We thank D. Adlawan, N. Gonzaga-Mosot and J. Tonga for their help with interviews, the local operators and communities for their support in completing this research, S. Trimble for cartography, and two reviewers for their valuable comments. This research was supported by the Social Sciences and Humanities Research Council of Canada under Grant 435-20150600 (PD) and by a PADI Foundation Grant (JZ).

Author contributions Study design, fieldwork: JZ, GA, JL, SS, AP, $\mathrm{RR}, \mathrm{PD}$; data analysis and writing: JZ, GA, SS, JK, AP, RR, PD.

\section{Conflicts of interest None.}

Ethical standards This research abided by the Oryx guidelines on ethical standards, and was approved by the University of Victoria's Human Research Ethics Board (Ethics Protocol Number \#15-434). We received prior informed consent to carry out this research, from the mayors of the communities of Donsol, Oslob, Pintuyan and Talisayan.

\section{References}

Alava, M.N.R., Dolumbaló, E.R.Z., Yaptinchay, A.A. \& Trono, R.B. (2002) Fishery and trade of whale sharks and manta rays in the Bohol Sea, Philippines. In Elasmobranch Biodiversity, Conservation and Management: Proceedings of the International Seminar and Workshop (eds S.L. Fowler, T.M. Reed \& F.A. Dipper), pp. 132-148. IUCN, Gland, Switzerland.

Almendral, A. (2018) In the Philippines, dynamite fishing decimates entire ocean food chains. The New York Times. nytimes.com/2018/ 06/15/world/asia/philippines-dynamite-fishing-coral.htm [accessed 20 April 2019]. 
Araujo, G. \& Labaja, J. (2017) Whale Sharks of Northern Mindanao: Hunters to Spotters? Progress Report, The Rufford Foundation. rufford.org/files/20000-2\%20Progress\%2oReport.pdf [accessed 23 January 2019].

Araujo, G., Lucey, A., Labaja, J., So, C.L., Snow, S. \& Ponzo, A. (2014) Population structure and residency patterns of whale sharks, Rhincodon typus, at a provisioning site in Cebu, Philippines. PeerJ, 2, e543.

Araujo, G., Snow, S., So, C.L., Labaja, J., Murray, R., Colucci, A. et al. (2017) Population structure, residency patterns and movements of whale sharks in Southern Leyte, Philippines: results from dedicated photo-ID and citizen science. Aquatic Conservation: Marine and Freshwater Ecosystems, 27, 237-252.

BENNETT, N.J. (2016) Using perceptions as evidence to improve conservation and environmental management. Conservation Biology, 30, 582-592.

Buckley, R. (1994) A framework for ecotourism. Annals of Tourism Research, 21, 661-669.

Cisneros-Montemayor, A.M., Barnes-Mauthe, M., Al-Abdulrazzak, D., Navarro-Holm, E. \& Sumaila, U.R. (2013) Global economic value of shark tourism: implications for conservation. Oryx, 47, 381-388.

Guest, G., Bunce, A. \& Johnson, L. (2006) How many interviews are enough? An experiment with data saturation and variability. Field Methods, 18, 59-82.

Holmes, C.M. (2003) The influence of protected area outreach on conservation attitudes and resource use patterns: a case study from western Tanzania. Oryx, 37, 305-315.

IgNACIO, R.J.N. (2018) Impact of illegal fishing flagged to LGUs. Business World. bworldonline.com/impact-of-illegal-fishingflagged-to-lgus [accessed 20 April 2019].

KING, T.D. (1997) Folk management and local knowledge: lobster fishing and tourism at Caye Caulker, Belize. Coastal Management, $25,455-469$

McCoy, E., Burce, R., David, D., Aca, E.Q., Hardy, J., Labaja, J. et al. (2018) Long-term photo-identification reveals the population dynamics and strong site fidelity of adult whale sharks to the coastal waters of Donsol, Philippines. Frontiers in Marine Science, $5,271$.

Meekan, M. \& Lowe, J. (2019) Does provisioning for tourism harm whale sharks at Oslob? A review of the evidence and reply to Ziegler et al. (2018) Tourism Management, 75, 626-629.

Mintzer, V.J, Schmink, M., Lorenzen, K., Frazer, T.K., Martin, A.R. \& Da Silva, V.M.F. (2015) Attitudes and behaviors towards Amazon River dolphins (Inia geoffrensis) in a sustainable use protected area. Biodiversity and Conservation, 24, 247-269.

Nilsson, D., Gramotnev, G., Baxter, G., Butler, J.R.A., Wich, S.A. \& McAlpine, C.A. (2016) Community motivations to engage in conservation behavior to conserve the Sumatran orangutan. Conservation Biology, 30, 816-826.

Pegas, F.V., Coghlan, A., Stronza, A. \& Rocha, V. (2013) For love or for money? Investigating the impact of an ecotourism programme on local residents' assigned values towards sea turtles. Journal of Ecotourism, 12, 90-106.

Philippine Statistics Authority (2019) Philippine Standard Geographic Code. psa.gov.ph [accessed 12 March 2020].

Pierce, S.J. \& Norman, B. (2016) Rhincodon typus. In The IUCN Red List of Threatened Species 2016: e.T19488A2365291. dx.doi.org/10. 2305/IUCN.UK.2016-1.RLTS.T19488A2365291.en [accessed 27 February 2020].

PIne, R. (2007) Donsol Whale Shark Tourism and Coastal Resource Management: a Case Study of the Philippines (eds C. Salao \& A. Honasan), pp. 39. WWF-Philippines, Quezon City, Philippines.
Schleimer, A., Araujo, G., Penketh, L., Heath, A., McCoy, E., LABAJA, J. et al. (2015) Learning from a provisioning site: code of conduct compliance and behaviour of whale sharks in Oslob, Cebu, Philippines. PeerJ, 3, e1452.

Seales, L. \& Stein, T. (2012) Linking commercial success of tour operators and agencies to conservation and community benefits in Costa Rica. Environmental Conservation, 39, 20-29.

Spiteri A. \& Nepal, S.K. (2006) Incentive-based conservation programs in developing countries: a review of some key issues and suggestions for improvements. Environmental Management, 37, 1-14.

Stem, C.J., Lassoie, J.P., Lee, D.R., Deshler, D.D. \& Schelhas, J.W. (2003) Community participation in ecotourism benefits: the link to conservation practices and perspectives. Society \& Natural Resources, 16, 387-413.

STronZA, A. (2007) The economic promise of ecotourism for conservation. Journal of Ecotourism, 6, 210-230.

The Manila Times (2013) Country's fishing grounds 'almost depleted'. The Manila Times. manilatimes.net/countrys-fishinggrounds-almost-depleted/21435 [accessed 20 April 2019].

Thomson, J.A., Araujo, G., Labaja, J., McCoy, E., Murray, R. \& Ponzo, A. (2017) Feeding the world's largest fish: highly variable whale shark residency patterns at a provisioning site in the Philippines. Royal Society Open Science, 4, 170394.

VASKe, J.J. (2008) Survey Research and Analysis: Applications in Parks, Recreation and Human Dimensions. Venture Publishing, State College, USA.

Venables, S., Winstanley, G., Bowles, L. \& Marshall, A.D. (2016) A giant opportunity: the economic impact of manta rays on the Mozambican tourism industry-an incentive for increased management and protection. Tourism in Marine Environments, $12,51-68$.

Walpole, M.J. \& Goodwin, H.J. (2001) Local attitudes towards conservation and tourism around Komodo National Park, Indonesia. Environmental Conservation, 28, 160-166.

Wardle, C., Buckley, R., Shakeela, A. \& Castley, J.G. (2018) Ecotourism's contributions to conservation: analysing patterns in published studies. Journal of Ecotourism, published online 14 March 2018.

Wong, C.M., Conti-Jerpe, I., Raymundo, L.J., Dingle, C., Araujo, G., Ponzo, A. et al. (2019) Whale shark tourism: impacts on coral reefs in the Philippines. Environmental Management, 63, 282-291.

Ziegler, J., Araujo, G., Labaja, J., Legaspi, C., Snow, S., Ponzo, A. et al. (2019a) Measuring perceived crowding in the marine environment: perspectives from a mass tourism 'swim-with' whale shark site in the Philippines. Tourism in Marine Environments, $14,211-230$.

Ziegler, J. \& Dearden, P. (in press) Protecting an Endangered species: the role of whale shark tourism as an incentive-based conservation approach. In Saving Earth's Largest Fish: Biology and Conservation of Whale Sharks. Taylor \& Francis/CRC Press, Boca Raton, USA.

Ziegler, J., Silberg, J.N., Araujo, G., Labaja, J., Ponzo, A., Rollins, R. et al. (2018) A guilty pleasure: tourist perspectives on the ethics of feeding whale sharks in Oslob, Philippines. Tourism Management, 68, 264-274.

Ziegler, J., Silberg, J.N., Araujo, G., Labaja, J., Ponzo, A., Rollins, R. et al. (2019b) Applying the precautionary principle when feeding an endangered species for marine tourism. Tourism Management, 72, 155-158.

Ziegler, J., Silberg, J.N., Araujo, G., Labaja, J., Ponzo, A., Rollins, R. et al. (2019c) Using long-term integrated research programs to improve whale shark tourism at Oslob, Philippines. Tourism Management, 74, 297-299. 